\title{
ECONOMIC AND FINANCIAL CRISES IN EMERGING MARKET ECONOMIES: OVERVIEW OF PREVENTION AND MANAGEMENT
}

\author{
Martin Feldstein \\ Working Paper 8837 \\ http://www.nber.org/papers/w8837 \\ NATIONAL BUREAU OF ECONOMIC RESEARCH \\ 1050 Massachusetts Avenue \\ Cambridge, MA 02138 \\ March 2002
}

The views expressed herein are those of the author and not necessarily those of the National Bureau of Economic Research.

(C) 2002 by Martin Feldstein. All rights reserved. Short sections of text, not to exceed two paragraphs, may be quoted without explicit permission provided that full credit, including (C) notice, is given to the source. 
Economic and Financial Crises in Emerging Market Economies:

Overview of Prevention and Management

Martin Feldstein

NBER Working Paper No. 8837

March 2002

JEL No. F3, F4, O1

\begin{abstract}
This is the introductory chapter to an NBER conference volume that examined the lessons to be drawn from the financial and currency crises of the late 1990s. The paper does not attempt to summarize the specific content of that meeting but provides the author's personal conclusions about crisis prevention and management.

The first part of the paper deals with policies of the emerging market economies that affect the likelihood of crises, including exchange rate regimes, capital account convertibility, foreign exchange liabilities and reserves, domestic credit structure, and financial supervision. The paper then considers policies of industrial countries that affect the risk of crises in emerging market economies, including exchange rate instability, interest rates, banking supervision, trade policy, and the provision of a lender of last resort facility.

The second half of the paper deals with the way that the crises were managed by the IMF and attempts to answer the following questions: (1) Have the crises been resolved, permitting the crisis countries to return to solid economic growth and to achieve renewed access to international capital markets? (2) Did the IMF stabilization policies resolve the crisis with as little economic pain as possible? (3) Did the agreed structural reforms actually occur and, if so, were they successful? (4) How did the experience of the crisis countries affect the incentives of lenders, borrowers, and countries facing crises in the future? (5) Were the actions of the IMF politically legitimate for an international agency? (6) What were the political consequences of the crises and the policies that followed?
\end{abstract}

Martin Feldstein

NBER

1050 Massachusetts Ave.

Cambridge, MA 02138 
Economic and Financial Crises in Emerging Market Economies:

Overview of Prevention and Management

\section{Martin Feldstein ${ }^{*}$}

Financial and currency crises have occurred for as long as there have been financial markets. But the crises in the emerging market economies since the late 1990s were more global and potentially more damaging to economic and political stability than the crises of the past. The events that began in Thailand in 1997 eventually enveloped several countries of east Asia, as well as Russia, Turkey, and key Latin American economies. Finding ways to reduce the risk of future crises and to improve the management of crises when they do occur is a policy challenge of great importance.

The crises that hit Latin America in the 1980s were significantly different from those of the 1990s. The governments of Latin America had borrowed heavily from foreign commercial banks during the 1970s, encouraged by very low real interest rates and by high prices for their commodity exports. When real interest rates rose sharply at the end of that decade and an American recession reduced the demand for Latin American exports, the borrower countries were unable to service their debts. As a result, the major money center banks of the United

"Professor of Economics, Harvard University, and President of the National Bureau of Economic Research. This paper will serve as an introduction to the NBER conference volume Economic and Financial Crises in Emerging Market Countries (Chicago: University of Chicago Press, 2002). That volume contains a combination of background papers by economists on various aspects of the financial crises and personal statements of 17 individuals who have dealt with the recent financial crises as officials of U.S. and foreign governments and of international organizations, private sector executives, and academic analysts. This introductory chapter benefitted from what I learned at that conference as well as from the papers and discussions at two other NBER conferences: Preventing Currency Crises in Emerging Markets, edited by Sebatian Edwards and Jeffrey Frankel (Chicago: University of Chicago Press, 2002) and Managing Currency Crises in Emerging Markets, edited by Michael Dooley and Jeffrey Frankel (Chicago: University of Chicago Press, 2002). I also benefitted from the NBER meetings on individual crisis countries; the discussions at those meetings are summarized by John McHale on the NBER web site at The NBER Project on Exchange Rate Crises. Some of my earlier views on these issues were presented in "Refocusing the IMF," Foreign Affairs, March/April 1998, "A Self-help Guide for Emerging Markets", Foreign Affairs, March/April 1999, and "No New Architecture," The International Economy, September/October 1999. 
States and Europe were significantly impaired, causing widespread concern about the possibility of a systemic banking crisis in the industrial world. The Latin American governments were forced to reduce the spending that had been financed by foreign credits and to deflate their economies even further in order to increase net exports so that they could make interest and principal payments on their external debt. The combination of these actions, a general recovery of global demand, a decline of real interest rates, and some forced write-downs of debt eventually brought the crisis to an end. But even after it was resolved, incomes in Latin America remained below their pre-crisis levels for some time.

Governments and banks learned some important lessons from this experience. The Latin American governments financed their subsequent budget deficits in their domestic capital markets to a much greater extent ${ }^{1}$ and the commercial banks of the industrial counties reduced their lending to foreign governments. Although large current account deficits continued in several countries, they were financed primarily by a combination of private borrowing in international bond markets, equity flows, and foreign direct investment.

The late 1980s and the 1990s saw a very substantial expansion of the global capital market with rapid increases in private debt and equity flows and in foreign direct investment. ${ }^{2}$ This expansion reflected a wide variety of changes in the global political environment, in financial technology, and in investors' preferences. The collapse of the Soviet Union and the general shift to more democratic and market-oriented policies around the world increased the attractiveness of lending and investing in the emerging market countries and the desire by their governments to attract foreign equity capital. Technological developments facilitated global portfolio management and the retail index funds that shifted debt and equity investments to emerging economies. Portfolio investors seized the opportunity to diversify portfolios in pursuit of the higher returns and the lower overall volatility that they believed would follow such diversification.

${ }^{1}$ Argentina was an exception to this, borrowing heavily in dollars in the international markets to finance its government deficits.

${ }^{2}$ See the papers and personal commentaries in Martin Feldstein, International Capital Flows (Chicago: University of Chicago Press, 1999) for analyses of these capital flows. 
Avoiding the mistakes of the 1970s did not however prevent a return of international financial crises. In retrospect, the crises of the 1990s were due primarily to a combination of unsustainable current account deficits, excessive short-term foreign debts, and weak domestic banking systems. Although the experience in each crisis country was unique, one or more of these adverse conditions was present in each case.

The industrial countries responded to these crises both directly and through the International Monetary Fund with substantial packages of financial support and with the imposition of wide-ranging requirements of domestic economic reforms. But now, more than four years after the crises began, the major crisis countries have neither returned to their precrisis rates of economic growth nor achieved the structural reforms that the IMF had tried to impose.

What then are the lessons to be learned from this experience? What can be done to reduce the risk of recurrent crises in emerging market countries? And how can the crises that will occur in the future be managed in a way that reduces the direct adverse consequences of dealing with those crises and that also discourages behavior by emerging market countries and by foreign creditors that increases the risk of future crises?

Although much has been learned about the answers to these questions, there is no general agreement about all of these issues among economists or among others who have dealt with these problems. Although the research and discussion in the NBER project has strongly influenced my thinking, what follows is my personal view rather than an attempt to summarize the background and research papers that appear in this and related NBER volumes or in the personal statements and discussion summary in this volume. They speak eloquently for themselves.

\section{Reducing the Risk of Financial and Currency Crises in Emerging Markets}

\section{Fixed Exchange Rates, Current Account Deficits, and Debt Deflation}

A primary cause of the crises that began with Mexico in the mid-1990s and continued in east Asia in the late 1990s was a large and growing current account deficit caused by a fixed exchange rate. The experience in Thailand illustrates this very dramatically. Thailand fixed the value of the bhat at 25 bhat to the dollar, a level that initially made Thai exports very 
competitive. As the dollar fell relative to the Japanese yen, the bhat fell with it, increasing the competitiveness of Thai products in Japanese and other markets. The stable dollar-bhat exchange rate encouraged Thai companies to finance themselves by borrowing dollars (which had lower interest rates than bhat) even when their only sales revenue were in bhat since they were told by the Thai government that the bhat-dollar rate would remain unchanged, a statement quite consistent with their observation over several years. Thai banks also borrowed dollars on the world market and lent them to these local companies, comfortable in the knowledge that their dollar assets and liabilities were balanced even though the Thai borrowers did not earn dollars directly but depended on converting their bhat incomes into dollars to service their dollar debts.

Eventually, however, the bhat became overvalued, reflecting rising domestic prices in Thailand and an appreciating dollar, particularly relative to the Japanese yen. Thailand's current account deficit grew rapidly, reaching four percent of GDP in the early 1990s and surging to eight percent of GDP by 1997. This unsustainable current account deficit caused substantial selling of bhat by foreign investors. The Thai government responded by defending the bhat with their foreign exchange reserves and then used the forward market to support the bhat so that they could appear to maintain their foreign exchange reserves even as their true net position deteriorated. Eventually, the negative forward market position equaled the country's net reserves. At that point, the Thai government had no choice but to stop pegging the value of the currency. The bhat floated to nearly 50 bhat to the dollar, half of its pre-crisis value.

This fall in the value of the bhat caused the bhat-value of dollar-denominated debt to double. For the many companies that were both highly leveraged in dollars and dependent on bhat earnings to pay their dollar liabilities, the doubling of the debt meant bankruptcy. The banks that had made loans to those companies were also bankrupt and unable to pay the foreign creditors who had loaned them dollars during the fixed exchange rate period. The widespread bankruptcies caused a sharp economic downturn.

Thailand was not unusual in experiencing the ravages of debt deflation when its currency devalued. The experience during all of the crises shows that the existence of large amounts of private debt denominated in dollars or other hard currencies is the most serious source of economic hardship facing the economy. When the domestic currency comes down in value, a 
bank or nonfinancial company that has a large dollar debt sees its indebtedness rise sharply in the local currency. Avoiding large amounts of dollar-denominated debt, and particularly private dollar debt, is probably the most useful thing that a country and corporation can do to reduce the serious consequences of a currency fall. This is true of financial institutions as well as of nonfinancial companies.

Countries adopt fixed (but potentially adjustable) exchange rates ${ }^{3}$ for a variety of reasons. A fixed exchange rate can provide a nominal anchor that helps the country to achieve price stability. A fixed exchange rate encourages an inflow of foreign capital and, by appearing to eliminate exchange rate volatility, can keep interest rates lower than they would otherwise be. But a fixed exchange rate also brings with it the danger that the real exchange rate becomes overvalued, either because the domestic price level increases more rapidly than that of competing countries or because of a relative decline in the nominal value of the competing currencies to which the home currency is not pegged. Foreign lenders may be induced by higher interest rates to continue financing a growing current account deficit but eventually the fear of devaluation overcomes the high interest rate reward. At that point, lenders will no longer extend loans when they are due or roll-over bond debt that matures. This problem is exacerbated by domestic residents who convert funds and take them out of the country. When these things happen, the currency declines, possibly by a large amount.

Governments that have fixed their exchange rate at an unsustainable level are reluctant to devalue as soon as they should because devaluation is itself painful. Doing so raises domestic inflation and, when domestic debts are written in the foreign currency, causes widespread losses and possible bankruptcies. Those who would lose are often politically well connected. In addition, delaying provides the opportunity for a spontaneous correction of the current account deficit if the real exchange rate of the competing currency appreciates. Unfortunately, waiting

${ }^{3}$ All so-called fixed exchange rates are potentially adjustable unless the country literally gives up its currency (as the members of the European Economic and Monetary Union have done.) Even a currency board country like Argentina has a potentially adjustable exchange rate, a fact supported by the currency risk in the interest rate in excess of the country risk. 
longer to devalue often just exacerbates the trade imbalance and makes the cost of devaluation greater when it does occur.

The obvious alternative to a fixed but adjustable exchange rate is a floating currency. If the currency floats, a growing current account deficit will generally be self-correcting because the value of the currency declines as financial market participants sell the currency in response to the increased current account deficit in order to protect themselves from a potential future currency decline. While a floating currency introduces volatility that makes business more difficult for exporters and for those companies that compete with imports from abroad, the pain caused to them is much less than the pain of the crises and bankruptcies when an overvalued fixed currency falls in a sharp devaluation. Experience in Brazil, Israel, and elsewhere shows that the potential inflationary effect of a floating exchange rate can be dealt with by tightening monetary policy to achieve the country's desired rate of inflation.

Although there is a growing consensus among economists in favor of floating exchange rates, many countries have "managed floats", i.e., exchange rate systems in which they intervene extensively to stabilize the value of the currency. In principle, such a system might be an improvement on a clean float if officials increase the short-term stability of the exchange rate while allowing the exchange rate to adjust in ways that offset current account imbalances and differences in inflation rates. In practice, however, it appears to be too difficult for officials to avoid the temptation to prevent a currency decline even when fundamentals point in that direction. The result is the same problems as those created in a more explicitly fixed-butadjustable exchange rate regime.

Despite the obvious problems with fixed exchange rates, there is still some professional support for fixed exchange rates that are supported by currency boards. In principle, such exchange rates are not adjustable at all but are permanently fixed by a mechanism that automatically raises interest rates by enough to maintain demand for the currency at its pegged exchange rate. Although Argentina, the leading currency board country, has (as of the time of this writing in October 2001) been able to maintain its fixed exchange rate vis-a-vis the dollar, its situation is precarious. Brazil, Argentina's largest competitor, has a floating exchange rate that has made the Brazilian real increasingly competitive and the Argentine peso increasingly 
uncompetitive. The result has been to create a growing trade deficit in Argentina, putting significant pressure on the currency that translates into extremely high real interest rates in Argentina. Those high interest rates produce substantial economic weakness and cause a ballooning of the government deficit because of the higher interest on the national debt and the lower taxes caused by the economic downturn.

Domingo Cavallo, the Finance Minister who established the currency board system in Argentina in order to end the hyperinflation that previously plagued his country, makes it clear in his comment in this volume that he does not see the currency board as a permanent arrangement. Instead, he spoke of looking ahead to a time when the Argentine currency would generally be perceived as undervalued so that its link to the dollar could be ended and the currency could float to a higher value. Since the conference at which he made these remarks, the sharp decline of the Brazilian real has caused a major increase in Argentina's current account deficit, thereby putting substantial downward pressure on its currency.

Argentina's fixed exchange rate system is made even more unstable by a full capital account convertibility that not only allows Argentinians to convert pesos to dollars at a fixed exchange rate of one peso per dollar but that also allows an unlimited export of those dollars. If the time comes when enough Argentinians fear an end of the fixed exchange rate and a peso devaluation, the capital outflow will force that collapse to occur.

In my judgement, the evidence from around the world during the past decade, as well as much evidence from earlier years, points clearly to the conclusion that any form of fixed put potentially adjustable exchange rate, including currency board arrangements, raises the risk of unsustainable current account deficits and a subsequent currency crisis. ${ }^{4}$

This has induced Ecuador to abandon its own currency in favor of using the U.S. dollar and has caused a number of economists to call for dollarization more generally in Latin America and elsewhere. Dollarization differs from a dollar based currency board in completely abolishing

${ }^{4}$ Despite the adverse experience with fixed-but-adjustable exchange rates, the International Monetary Fund continues its policy of not advising governments on the choice of exchange rate system. It explicitly supported the Argentinian currency board arrangement by a large loan in 2001. 
the local currency. There are three serious problems with such an approach. First, because the country has a different pattern of imports and exports than the United States, the exchange rate between the dollar and other currencies around the world that is suitable for the U.S. may lead to substantial trade deficits for the dollarizing country unless it is able to achieve a real devaluation by reducing its domestic price level, a difficult task at best. Second, cyclical fluctuations in demand cannot be modulated by automatic or induced interest rate changes since, except for default risk, the interest rate on dollar loans must be the same in the dollarized emerging market country as they are in the United States.

Third, because the central bank of the dollarized country does not have the ability to create dollars it cannot act as a lender of last resort if there is a run on any of the local commercial banks. Although residents use ordinary dollar bills for cash transactions, they also have checking and time deposit accounts that represent claims on dollars from their commercial banks. If residents become nervous about whether these "dollar" deposits can actually be shifted into dollars that can be held as currency or sent out of the country, they may create bank runs that the government cannot manage because it lacks sufficient dollars and the ability to create dollars. Dollarization does not seem any more likely to be a viable long-term strategy than a currency board.

\section{Capital Account Convertibility}

The issue of capital account convertibility is important in its own right. Many countries that have current account convertibility (i.e., that allow foreigners and local residents to buy and sell the currency for trade purposes) do not have capital account convertibility (i.e., do not allow the purchase and sale of the currency for portfolio investments.) Capital account convertibility can benefit a country by encouraging capital inflows and by permitting domestic residents to enjoy the benefits of international portfolio diversification. But capital account convertibility brings with it the possibility of much more volatile capital flows that can destabilize domestic financial markets and the exchange rate.

A compromise arrangement that can provide most of the advantages of foreign capital inflows while reducing the volatility that can result from speculative inflows and outflows has 
been developed in Chile. The Chilean government has from time to time taxed short-term capital inflows (by requiring that financial inflows be held in the country for a period of time without receiving interest), thus discouraging speculative inflows while still having the advantage of foreign direct investment and longer-term debt and equity capital.

\section{$\underline{\text { Financial Supervision }}$}

The gains from an open capital account are more likely to outweigh the potential adverse effects in a country where the domestic financial system is strong and well supervised. The crisis in Thailand was exacerbated by the Thai banks' policy of borrowing dollars from abroad and then lending those dollars to Thai companies. Although this appeared to be a reasonable activity as long as the exchange rate between the Thai bhat and the dollar was unchanged, it was in fact a very risky strategy because the Thai businesses generally did not have the ability to earn dollars. When the currency fell sharply relative to the dollar, the Thai banks were unable to collect on their loans. If the banking supervisors had been doing their job correctly, they would never have allowed the banks to accept large dollar liabilities offset by dollar loans that lacked real value because they depended on the fixity of the exchange rate.

The weakness of banking supervision and regulation was also a problem in Korea. When the Korean capital market was opened more broadly, some of the Korean nonbank financial institutions borrowed heavily abroad in dollars and then lent these funds to Korean firms or used them to speculate in high risk assets like Russian bonds. Even the major Korean banks and corporations borrowed dollars to finance activities in Korea. The crisis in Korea occurred when foreign investors recognized that the sum of the short-term dollar liabilities of the Korean public and private sectors exceeded the country's foreign exchange reserves. They worried correctly that if any of the country's creditors chose not to roll over the loans and the bond debt that were coming due in the next year, the remaining creditors could not all be paid. When they saw that, many gave notice that they would not renew their credit, forcing Korea to use up its foreign exchange reserves and eventually to turn to the IMF for help in dealing with its crisis. Here too a crisis might have been avoided by better banking supervision and by regulation that limited the exposure to foreign currency liabilities. 
The soundness of the domestic financial system is important for local depositors as well as for foreign creditors. If depositors come to believe that the volume of bad loans and investments cause the liabilities of the domestic banks to exceed the real value of their assets, depositors will withdraw funds and precipitate a banking crisis. Although the risk of this can be reduced by the government's provision of complete deposit insurance, that encourages more risky lending by banks. Moreover, when large depositors fear that banking failures will lead to a currency depreciation, they will want to shift their funds to foreign banks even if there is deposit insurance in the domestic currency.

It is significant that the banking systems in so many of the crisis countries were weak and now remain insolvent or nationalized or both. Countries with strong banking systems and good bank supervision like Singapore avoided the difficulties that happened in the crisis countries. Brazil avoided the banking problems that affected so many of the others because a very large fraction of its total bank assets were in Brazilian government bonds. Argentina had an early crisis in which many banks failed but now has shifted the ownership of most of its banking industry to foreign banks, primarily from the United States and Spain, that provide a much greater professionalism of management. Mexico recently changed its banking law to permit majority foreign ownership of its banks. Although many countries resist such foreign ownership for a variety of reasons, it does appear to be one way of improving banking practice quickly.

\section{Foreign Exchange Liabilities and Reserves}

An excess of short-term foreign currency liabilities over a nation's foreign exchange reserves readily precipitates a crisis. Countries find themselves in that situation not only because of the excessive currency risk taken by financial institutions and non-financial corporations but also because of the traditional policy of many emerging market countries of having foreign exchange reserves that are too small in the context of the current global capital markets. A traditional approach has been to hold foreign exchange reserves equal to three months of imports. While that standard might be relevant for countries without capital account convertibility, it is clearly not relevant when the country is exposed to large fluctuations in capital flows. 
There is of course no level of reserves that can protect an exchange rate that is fundamentally overvalued (as indicated by a large and growing current account deficit.) The purpose of reserves in a floating rate regime is to protect a country's currency against unwarranted speculative attacks. For that purpose the standard for judging the adequacy of reserves is the size of the speculative attack that might be mounted against the country. China, with reserves of more than $\$ 150$ billion, and Taiwan, with more than $\$ 100$ billion, do not have to worry about speculative attacks. Korea learned its lesson in 1997 and now also has reserves of more than $\$ 100$ billion.

A second measure of the adequacy of foreign exchange reserves is the size of reserves relative to the foreign currency liabilities that will be due in a year or less. It was a failure to have adequate reserves by this standard that caused the crisis in Korea. To improve this balance, it is easier and less costly for a country to limit its short-term liabilities than to increase its foreign exchange assets The government itself can avoid short-term borrowing and extend the duration of its debts as they come close to maturity. The Chilean system of mandatory deposits achieves much the same thing for private capital inflows.

But the absolute level of foreign exchange reserves, and not just those reserves in relation to short term liabilities, is important for deterring speculative attacks. Emerging market countries are nevertheless generally reluctant to hold adequate reserves because of the perceived high cost of doing so. Large reserves appear costly because these countries typically hold their reserves in U.S. Treasury bills which have a yield far below the country's own cost of borrowing dollars and far below the opportunity cost of those reserves as measured by the potential yield on real investments within the economy. Even so, that cost is small relative to the economic damage that would follow a successful speculative attack on the currency.

It is possible moreover to reduce the net cost of large reserves by holding reserves in a form that provides immediate liquidity but with a higher yield than Treasury bills. A country that holds a significant portion of its reserves in the form of a broadly diversified portfolio of foreign equities can expect a significantly higher rate of return and therefore a lower net cost of holding reserves. While such an equity fund would involve greater investment risk than a portfolio invested in U.S. Treasury bills, the overall risk that the country faces may be lower with a larger 
and riskier foreign exchange portfolio than with a smaller portfolio of safer assets, substituting some investment risk for less risk of speculative attack.

In short, there are five primary ways in which a country can reduce the risk of a currency crisis: (1) avoiding an overvalued currency by allowing the currency's value to float; (2) maintaining a substantial level of foreign exchange reserves; (3) keeping short term foreign exchange liabilities low relative to reserves; (4) maintaining a sound banking system; and (5) avoiding large amounts of dollar denominated debt, especially the debt of the private sector.

Although these policies can in principle avoid the fundamental factors that caused the crises of the 1980s and 1990s and discourage purely speculative "contagion" attacks, crises will no doubt continue to happen in the future. The fact that the crises of the 1990 s were caused by different conditions than those that caused the crises of the 1980s should, in itself, be a warning that conditions that we do not now anticipate may cause crises in the future. All that countries can do to protect themselves is to avoid the policies that caused crises in the past.

If a crisis does occur, the consequences for the economy will depend on how the crisis is managed and on the structural condition within the economy at the time of the crisis. Before discussing the management of crises, it is useful to consider how the policies of the industrial countries might be modified to reduce the risk of financial and currency crises in the emerging market economies.

\section{Policies of the Industrial Countries}

Although there are in principle a variety of things that the United States and other industrial countries could do to reduce the risk of crises in the emerging markets, there is in fact little likelihood that those things will be done to an extent that will have an appreciable effect on the risk of future crises. It is nevertheless worth reviewing some of the key suggestions that have been made for changes in industrial country policies.

\section{Stabilizing exchange rates among the industrial countries.}

Fluctuations of the exchange rates among the dollar, the yen, and the euro can exacerbate trade deficits of emerging market countries, precipitating balance of payment crises. A country that has dollar denominated liabilities but that earns yen or euros from its exports could see its 
ability to service its debts suffer if the dollar appreciates relative to the other currencies. The rise of the dollar in the 1980s hurt Latin American economies, the fall of the yen in the mid-1990s hurt the economies of south east Asia, and the decline of the euro exacerbated Argentina's trade deficit. Similarly, a country that imports dollar denominated products (like oil) but exports to Europe or Japan would have difficulty paying for its imports if the dollar appreciates relative to the other G-3 currencies. It is not surprising therefore that the emerging market countries and several economists have spoken of the advantages of stabilizing the exchange rates among the dollar, yen and euro.

In reality, there is little prospect that the US and other countries will pursue deliberate policies to stabilize their exchange rates. To some extent, more stable exchange rates among the three major industrial currencies will occur as a result of policies aimed at low inflation and low budget deficits. But going beyond that to stop fluctuations would require adopting a common monetary policy, something that none of the governments or central banks would contemplate. ${ }^{5}$

The emerging market countries should therefore act on the assumption that the major exchange rates will vary. That implies a further reason to float and to avoid debt that is denominated in dollars or any other single currency. A country that does borrow abroad might protect itself from currency fluctuations by borrowing in a mix of currencies.

\section{Avoiding High Interest Rates}

Countries that borrow in dollars or other hard currencies are directly affected by any increase in the interest rates in the home countries of those currencies. Market participants also believe that an increase in the dollar interest rate causes interest rates on emerging market loans to rise by more than an equal amount. Since there is no prospect that the industrial countries will modify their domestic monetary policy in order to reduce adverse effects on the emerging market countries, private and public borrowers in those countries must take into account the possibility of interest rate moves that are not based on local conditions, making the optimal debt level less than it would otherwise be and increasing the optimal maturity of that debt.

${ }^{5}$ Alternatively, without a common monetary policy, attempts to reduce currency fluctuations would lead to fluctuations in interest rates that could be as unsettling to the emerging market economies as the exchange rate fluctuations. 


\section{Opening Markets to Emerging Market Products}

Opening the industrial country markets to increase imports of textiles and agricultural products from the emerging market countries would raise the standard of living in the export countries as well as among the importers. It is an idea widely supported by economists and opposed by the special interests in the industrial countries that would be hurt by the import competition. Progress toward greater market opening will therefore continue to be slow. Moreover, such market opening might do little to reduce the risk of economic crises. The more open markets would provide a permanent improvement in the level of exports but might not change the net balance of trade once imports had adjusted to the new ability to finance increased imports.

\section{Regulating Lending by Private Industrial Country Creditors}

After both the Latin American crisis of the 1980s and the Asian crisis of the 1990s there was widespread agreement that there had been too much borrowing by private and public entities in the crisis countries. When there is too much borrowing, there is also too much lending. Many experts therefore suggest that steps be taken to reduce the amount of lending to emerging market countries and to increase creditors' sensitivity to the risks involved.

Bank supervisors in industrial countries do provide oversight on the amount and concentration of emerging market country lending by the banks for which they are responsible. This is reinforced by the Basel capital rules that require more capital per dollar of loans or investments in emerging market countries, although these rules were misleading when they treated the sovereign debt of Mexico and Korea as free of credit risk because both countries are members of the OECD. Requiring banks to mark credit portfolios to market would be another discipline on bank lending and risk taking.

The shift from bank lending to the emerging market countries in the 1980s to the international bond market in the 1990s reduced the role of bank supervision and capital requirements in limiting credit to the emerging market countries. Bond finance generally places assets in less leveraged institutions (pension funds, insurance companies, etc) and reduces the risk of systemic damage to the industrial country financial institutions. But this dispersion of ownership may encourage a greater amount of lending and make it difficult for the creditor 
countries to track the amount loaned by entities within its borders, let alone the global amount of lending to particular borrowing countries. When conditions look favorable in emerging markets, it is easy for lenders to rush in, unaware of the total amount of debt being incurred by the countries to which they are lending. Even if the credit standing of the borrowers is good, the accumulation of substantial debt may strain foreign exchange availability.

\section{Providing a Lender of Last Resort}

A nation's central bank can prevent runs on solvent commercial banks by providing sufficient liquidity to assure depositors and other creditors that they have nothing to fear. They do so by lending against good but illiquid collateral. The very existence of such a lender of last resort helps to reduce the risk of domestic financial crises.

There is no such institution in the international economy that can lend foreign exchange to solvent central banks to assure foreign creditors that they need not fear a collapsing currency. Some have suggested that the IMF or the Bank for International Settlements might play such a role. (The IMF programs since the Thailand crisis of 1997 have involved large amounts of financial assistance but these payments are conditioned on various structural reforms and are not available immediately, the key requirement of a lender of last resort.) Opponents of creating such a facility note that central banks do not have the illiquid but good collateral that are the key to the domestic lender-of-last-resort transactions. Opponents also worry that the availability of such a lender in the international context would create moral hazard problems, encouraging more commercial lending to the emerging market countries in the expectation that the loans would be repaid with the funds provided by the lender of last resort.

In practice, the potential for an international analog of the domestic central bank as lender of last resort will fail for the simple reason that the IMF does not have the resources to "lend freely" (as Bagehot advised in his classic discussion of the lender of last resort) and because the debtor countries do not have the "good collateral" (against which Bagehot said such lending should be done). Indeed, after a half-decade of unprecedentedly large IMF-led packages, the future is likely to involve much less availability of official funds.

The emerging market countries must therefore be prepared to protect themselves against the unwarranted currency attacks and bank runs associated with "pure contagion" and with 
deliberate attempts at destabilizing speculation. For those countries that have full capital account convertibility, that means accumulating large enough reserves on their own to deter speculators and reassure domestic and foreign investors.

\section{Managing Financial and Currency Crises in Emerging Markets}

Although the crisis countries must manage their own recoveries, they have done so in recent years under the close supervision and direction of the International Monetary Fund. The Fund has itself been guided to a large extent by the preferences of the United States government and, to a lesser extent, by the preferences of the other major G7 countries. The Fund's approach has differed in many ways from its behavior in earlier crises, particularly in the extent to which it has used very large low-interest loans to induce and enforce wide-ranging conditions of structural economic reform. It is important to assess whether the new IMF policies were successful in dealing with the crises of the 1990s and how those policies might be modified in the future.

In doing so, I will arrange my comments as answers to six questions:

(1) Have the crises been resolved, permitting the crisis countries to return to solid economic growth and to achieve renewed access to international capital markets?

(2) Did the combination of monetary and fiscal policies and IMF loans resolve the crisis with as little economic pain and damage as possible?

(3) Did the structural reforms required by the IMF agreements actually occur and, to the extent that they did, were they successful?

(4) How did the experience of the crisis countries affect the incentives of others: the lenders to be more careful in the future, the borrowers to reduce future risks, and countries facing potential future crises to come earlier to the IMF for assistance?

(5) Were the actions of the IMF politically legitimate for an international agency dealing with sovereign nations?

(6) What were the political consequences of the crises and the policies that followed?

Needless to say, these questions cannot be answered unambiguously and careful students 
of the data can reach different conclusions. I offer my own evaluation knowing that readers will consult the views of others in this volume and elsewhere.

It is useful to begin by putting the current crisis management in the context of the IMF's history. When the IMF was established after World War II, the major industrial countries were its main concern. Those countries operated fixed but adjustable exchange rate systems, often with some form of capital control, within the framework of the gold-dollar standard. Balance of payments crises arose when excess domestic demand or inflation-induced currency misalignments caused trade deficits that led to unsustainable pressure on the exchange rate. The IMF responded with a combination of short-term balance of payments assistance (to allow the crisis country to pay for imports) while advising the crisis country to devalue its currency (to make its exports more competitive and to reduce its imports) and to deflate domestic demand by contractionary monetary and fiscal policy (to reduce imports, create capacity for exports, and end the inflation that was frequently a cause of the currency misalignment.) This devalue-and-deflate became a standard part of the IMF prescription for dealing with currency crises even when, as we shall see, such explicit deflation strategy was not necessary. In time, the industrial countries generally abandoned the system of fixed-but-adjustable exchange rates in favor of floating and the balance of payments crises ceased to be a significant problem.

The 1980s saw Mexico and then nearly all of the Latin American countries face serous crises because of an inability to service their foreign debt. That debt generally took the form of borrowing by the governments from the commercial banks of the United States and other major industrial countries. The ability of the governments to continue attracting funds and to service their debts was undermined in the early 1980s by a combination of factors including the sharp appreciation of the dollar, the dramatic rise of real dollar interest rates, and a global recession that reduced the demand for and prices of the products of the Latin American economies. The IMF responded with short term loans that allowed the debtor countries to meet at least part of their immediate debt service obligations and then focused its efforts on three things: advising the defaulting countries on the fiscal and monetary policies needed to achieve a sustainable current account balance; bringing borrowers and creditors together to negotiate debt restructuring, and monitoring the fiscal and monetary performance on behalf of the creditors. 
The next challenge facing the IMF was providing assistance to the countries of Eastern Europe and the former Soviet Union as they sought to move from being communist satellites of Russia to independent market economies. The IMF provided substantial technical assistance on a wide range of subjects including privatization, tax systems, commercial legal structures, central banking, commercial banking, and securities markets.

The crises of the 1990s that began in Thailand and spread among the southeast Asian countries and to Latin America differed from the earlier crises in two basic ways: the debts were no longer concentrated in the commercial banks of the industrial countries but had been shifted to bonds and securitized loans; and the debtors were no longer the sovereign governments but were the private commercial banks and nonfinancial corporations in those countries. The crises arose, as I noted in the earlier part of this chapter, from three primary sources: current account deficits caused by "fixed but adjustable" exchange rates that had become overvalued; excess amounts of foreign debt that could not be serviced in the short-run if creditors were not willing to roll over loans and bonds because the debt due in the short run exceeded the countries' foreign exchange reserves; and weak banking systems that led to bank runs by domestic and foreign creditors.

Although the IMF's response to these crises varied from country to country, the basic approach was the same in each case. The Fund prescribed floating the currency, since the old fixed rate could not be defended, but mandated high interest rates and tight fiscal policy to limit the extent of the currency's decline and to reduce the budget deficit. It developed structural reform plans covering a wide range of areas, including reform of commercial and central banking, ending government support for private companies, opening product and capital markets, changing labor laws and corporate governance rules, eliminating subsidies for various products, etc. These extensive and detailed structural reforms were without precedent in the IMF's dealing with the industrial countries in the 1950s and 1960s or with the Latin American crisis countries in the 1980s. Rather they were similar in style to the technical assistance given to countries of eastern European and the former Soviet Union in the early 1990s. These macroeconomic policies and structural reforms were embodied in Letters of Intent that, in principle, bound the crisis country to comply. In exchange for their agreement, the crisis countries received highly 
subsidized loans that was larger than anything that had ever been contemplated before in an IMF program. Korea's, for example, was $\$ 57$ billion. The loans were to be paid out gradually as the country showed that it was living up to its promises and achieving the structural reform goals set by the IMF.

The IMF described the big loan packages as a way to rebuild reserves and to renew market confidence in the crisis country. In practice, they were used to pay creditors and were only made available with such lags and subject to such strong but ambiguous conditions that the future portions of the loans could not provide much comfort to foreign or domestic creditors. Their purpose appeared to be to convince the crisis countries to accept the IMF's terms and to give the political leaders of each country the political cover with its own population.

With that brief description as background, I turn to the six questions listed above as the framework for evaluating the management of the crises and the lessons for the future.

Have the crises been resolved, permitting the crisis countries to return to solid economic growth and to achieve renewed access to international capital markets?

In general, the initial crises have been resolved, exchange rates have rebounded from their worst post-crisis levels and stabilized ${ }^{6}$, and positive growth has resumed. But there are many ways in which the crises continue to affect the countries. The growth rates have been much lower than they had been for the three decades before the crises, foreign lending has not resumed, stock markets are much lower than they were before the onset of the crisis, domestic lending to the private sector has essentially collapsed, and the domestic financial sector has not been restructured and strengthened.

The balance of payments improved substantially, driven initially by the collapse of import demand when the crisis countries went into deep recessions and continued with improved exports as a result of the sharp fall in the real exchange rate. The countries used the resulting current account surpluses to accumulate foreign exchange reserves, with Korea achieving $\$ 50$ billion by the end of 2000 .

${ }^{6}$ Indonesia is an exception; its currency continues to deteriorate. 
GDP declined sharply after the crisis began because of the collapse of credit and because the increased value of debt (measured in domestic currencies) impoverished many households and caused widespread business bankruptcies. The sharp decline of the currency however brought a sharp upturn in late 1998 and 1999 as exports boomed. But the year 2000 saw a sharp slowdown again to growth rates roughly half of what they had been from1970 to the start of the crisis.

It is of course difficult to know whether the recession and subsequent recovery would have been different without the IMF programs or with different policies. It is clear that the growth resumed because of the currency collapse and the resulting rise of exports and not because of anything more fundamental. Also by late 1999 the IMF had relaxed its tight monetary and fiscal policies.

It is significant that neither domestic lending nor foreign capital have come back to their previous levels. Similarly, the low level of real growth represents a failure to reestablish the previous performance of the "Asian tigers." This may be the result of the crisis itself or of the policies that weakened the economies, leaving a trail of corporate bankruptcies and insolvent banks that cannot provide the credit needed to achieve strong growth. The general public and the business community, even in Korea which might be considered the most successful of the crisis countries, may exhibit depressed levels of demand because of a shattering of confidence in the future and a concern that the economy could return to the same crisis conditions that they have recently escaped.

The IMF spoke of trying to restore confidence by a combination of large loans, tough monetary and fiscal policies, and widespread structural reforms. The combination of IMF statements, the extensiveness of the reforms and the delayed loan payouts may have had the opposite effect. When the crisis hit, the IMF did not try to argue that the problem was one of illiquidity (a temporary inability to pay) rather than insolvency (a permanent inability to repay), even for a country like Korea where the total foreign debt was only about one-third of GDP. Instead, the senior IMF officials insisted that all of the crisis countries were fundamentally sick characterized by political corruption, "crony capitalism," inadequate financial systems, etc. Foreign lenders and investors who had been happy to lend and invest until mid-1997 were 
shocked by the crisis and discouraged by the IMF's diagnosis. The extensive structural reforms called for by the IMF and the notion that the countries needed large loans that would only be paid out gradually and conditionally on meeting vague performance targets of structural reform was a further blow to confidence. All of this continues to weigh on the crisis countries' access to funds.

The situation in Indonesia is fundamentally worse than in the other crisis countries. In addition to the problems that affect the other countries, Indonesia is caught in a political crisis. The economic collapse and the IMF policies forced President Suharto's resignation. The small but economically important Chinese minority that Suharto had protected became the object of political and physical attacks and withdrew in part from the economic activities that they had previously performed. The political and military turmoil has depressed foreign lending and direct investment.

Did the combination of monetary and fiscal policies and IMF loans resolve the crisis with as little economic pain and damage as possible?

I agree with the critics of the IMF policies who claim that they caused unnecessary pain and damage in the early stage of the crisis because of excessively tight monetary and fiscal policies. I suspect that the short-run damage had a continuing adverse effect that depressed growth in 2000 and 2001 and beyond.

The IMF called for increases in taxes to reduce the budget deficits that would result from the reduced tax collection in the economic downturn and from the increase in public sector debt that would result from the government's assumption of some of the liabilities of banks and corporations. It is hard to understand why the IMF pursued such contractionary policies at a time when economic activity in the crisis economies was collapsing with real GDP growth dropping from more than five percent a year to equally large negative amounts.

I suspect that this reflects a continuation of old IMF policies designed for different problems. The balance of payments crises in the industrial countries in the $1950 \mathrm{~s}$ and $1960 \mathrm{~s}$ were often associated with low levels of national saving caused by excessive government borrowing that needed to be reversed. The Latin American crises in the 1980s were also 
characterized by large government budget deficits. In contrast, the Asian tigers had very high national saving rates, often exceeding 30 percent of GDP, and did not have large budget deficits.

The tight fiscal and monetary policies may also have been a holdover from the tradition of "devalue and deflate" as a way of dealing with balance of payments crises. Any such explicit policy action to deflate demand was unnecessary in the Asian crisis countries because of the debt deflation, i.e., because the market-driven currency devaluation caused a major deflationary effect by increasing the value of debts in the local currency. The devalue and deflate recipe, first advocated for the industrial countries by James Meade in the 1950s, was not intended for an economy with substantial international debt denominated in the foreign currency. The debt deflation in the Asian crisis countries meant widespread bankruptcies and a collapse of lending by local banks to the few credit-worthy borrowers that remained.

The economic downturn was particularly hard on the urban poor. In addition to widespread job losses, their real incomes were reduced by the rise in prices of imported products and of local products (especially food) that could now be sold on world markets for higher prices in the local currency. The rural poor were less hard hit because they were much less dependent on the market economy for food and housing and could gain by selling their agricultural products at higher domestic prices because of the currency devaluation.

The IMF's own self-evaluation ${ }^{7}$ now acknowledges that fiscal policy was too tight at the start of its programs but notes in its own self-defense that it subsequently and repeatedly allowed an easing of fiscal policy. The fact remains, however, that the fiscal policies required by the IMF made the cyclical situation worse. And whatever the desirability of limiting budget deficits, there was no attempt to balance the contractionary effects of higher tax rates with structural tax incentives to encourage more investment and economic recovery.

The IMF also required the crisis countries to raise interest rates sharply to defend their currencies. Real interest rates jumped to more than 20 percent in Korea and other countries. The Fund argued that this was important for three reasons. First, it believed that each falling currency put downward pressure on the other currencies in the region, leading to a continuing downward

\footnotetext{
${ }^{7}$ Refocusing the IMF - An IMF Issues Brief by IMF Staff (IMF: Issues Brief 2001/03, April 2001).

Fincurcris.intro.03052002.wpd $-23-$
} 
spiral of exchange rates. Second, it argued that currency stability was needed to achieve confidence in the country both at home and abroad. Third, currency stability was needed to prevent further debt deflation.

Balanced against this, of course, was the usual direct adverse effect of high interest rates on domestic demand. High debt to capital levels made the rise in interest rates particularly damaging, leading to a great increase in the volume of nonperforming loans and to widespread bankruptcies. This was particularly important because the crisis countries were experiencing not only a currency crisis but also a financial crisis characterized by nonperforming loans and widespread bank failures. Treating that financial crisis by itself would require increasing liquidity and lowering interest rates.

The Fund's argument that currency declines had to be checked by high interest rates to avoid a continuing downward spiral ignored the fact that at some point the currencies would be so undervalued that foreign speculators would want to buy them. A currency can attract investors even with a low interest rate if potential investors believe that it has fallen below its equilibrium level and can therefore be expected to appreciate. At some point, the falling currencies of the crisis countries would attract that kind of speculative buying. Even if all of the currencies in the region fell together, they would still be declining relative to the dollar, the European currencies, and probably the Japanese yen. The improved competitiveness that would result would provide a natural lower limit to their decline

In using high interest rates to stop the currency decline, the IMF was implicitly setting a target exchange rate for the currency. There is no reason to believe that the IMF actually had any idea of what an equilibrium exchange rate should be after the sharp declines in the exchange rates of some of the competing currencies and the collapse of much of the domestic supply side capacity. The Korean won, for example, fell from 800 won per dollar at the start of the crisis to 1800 won per dollar before bouncing back to 1100 won per dollar.

Even if the Fund was correct in concluding that it was appropriate to use high interest rates to stabilize the currency, it did nothing to offset the adverse effects of those high interest rates on the domestic economy. It would have been possible to use targeted fiscal policies to offset the adverse effects of the high interest rates on the domestic borrowers while maintaining 
the favorable international effect of high interest rates on the demand for the currency. For example, a corporate tax credit based on the amount of the company's debt in the year before the crisis would offset the destructive effect of the higher interest rate on the ability to service existing debt while not changing the marginal incentive effect to foreign and domestic investors.

The Fund, together with the World Bank and some of the G7 countries, provided large subsidized loans to the crisis countries. These loans permitted the countries to meet their immediate foreign currency obligations to foreign creditors and to provide foreign exchange to private borrowers so that they could meet their obligations. These loans, at very subsidized rates, were a strong incentive to accept the Fund's painful monetary and fiscal policies and the very intrusive structural policies that I discuss below. But unlike the loans of a domestic lender of last resort, they did not serve to prevent runs by domestic and foreign creditors or otherwise to offset the contractionary effects of the tight monetary and fiscal policies.

A domestic cental bank, acting as a lender of last resort, can stop runs by offering to lend without limit but against good collateral at a penal rate. The fact that it is known to be ready to provide such liquidity is enough to stop runs against sound but illiquid banks. The Fund does not have the resources to lend as much as the foreign debt of the crisis countries. The countries themselves do not have good collateral that would make lending safe for the Fund. And the Fund lends at a very much subsidized rate to make its loans attractive so that it can trade these subsidized loans for an acceptance of the Fund's conditionality.

The loans failed to reassure foreign lenders not only because they were limited in magnitude relative to the size of the country's external debt but also because the funds were not available immediately but could only be drawn over time as the country carried out its agreement with the Fund. Although the agreement was stated in a detailed Letter of Intent signed by the country, these agreements were frequently revised; Korea signed nine such letters of intent between December 1997 and July 2000. Many of the policies on which payouts were conditioned were unlikely to be done and others were so ambiguous that they left the Fund with substantial discretion about whether the debtor country had done enough to warrant payment by the Fund.

Some critics of the Funds policies point to Malaysia as an example of a country that was hit by the crisis but that chose not to go to the Fund for help. It declared a standstill on payments 
of foreign obligations and closed its international capital account. While there is some evidence that the decline in Malaysia was less than in other countries, this may be more a matter of timing than of better performance.

Looking ahead, the International Financial Institution Advisory Commission (known also as the Meltzer commission) has suggested that the IMF loans be replaced by Conditional Credit Lines (CCL) for which countries could prequalify. The IMF has accepted this idea as an additional option rather than as a replacement for its existing programs. The basic idea of the CCL is that a country that has sound macroeconomic and structural policies could apply for prequalification approval. If it is approved, it would have the right to draw funds in case its currency came under attack. The logic is that such an attack would be an unwarranted speculative attack that the country should be able to repulse. It is significant that no country has yet to apply for such CCL prequalification approval. Doing so might be regarded as a negative signal by market participants, an indication that the country expects its currency to be attacked. There is the further problem that the country would presumably have to be re-approved from time to time. If the country failed to be reapproved, that would be a very serious signal to the market, indicating that the credit line is no longer available and that the Fund had concluded that the country's policies were such that it no longer met the standard. It seems very unlikely that the CCL will ever be a viable alternative to direct debt workouts.

There is also much discussion about ways to enforce "private sector involvement," i.e., imposing some mandatory losses on private lenders. I find it strange that this is thought of as a matter for Fund policy rather than as a natural outcome of a debt workout in a future in which the IMF's funds are more limited than they have been in the past. If the debtor country cannot afford to make the payments that are due and the Fund does not have sufficient funds to permit it to lend that amount to the debtor country, the outcome must be a debt restructuring.Bank creditors will find that they have to roll over loans, delaying principal repayments and accepting lower interest rates. The private bond holders may also find that their bonds are exchanged for new ones with lower interest rates or rescheduled principal payments or both.

One of the serious problems in the debt workouts since 1997 has been the inadequate development of bankruptcy laws and procedures in many of the emerging market countries. 
When private creditors have made loans to private borrowers in an emerging market country, the usual remedy of the courts should be available. Creditors should be able to take property, including real estate and on-going businesses, if the debtors cannot make the promised payments.

Special bond provisions that allow actions to be taken by a majority of bond holders, rather than the unanimity rules that now prevail on most bonds, would facilities such debt restructuring. But, in doing so, they would make the bonds riskier to the creditors and would raise the cost of capital to high quality borrowers in the emerging market countries. It is not surprising that officials in Mexico and Brazil, for example, have opposed the introduction of such bonds.

Did the structural reforms required by the IMF agreements actually occur and, to the extent that they did, were they successful?

In responding to the crises that began in Thailand in 1997, the IMF required structural reforms by the debtor countries that were unprecedented in both range and detail as a condition for its approval and for the substantial funds that would accompany that approval. ${ }^{8}$ The specific conditions differed from country to country but all of the programs had substantially similar elements. The Fund stipulated that it would release successive tranches of its multibillion loans only as these changes were implemented.

Some of the structural reforms were aimed at improving the banking sector and the process of capital accumulation. Among other things, the Fund called upon the debtor country to make its central bank independent of the political authorities and committed to price stability. The Fund also ordered governments to stop interfering in the loans made by the commercial banks to industrial companies. The debtor countries were also told to recapitalize the commercial banks so that they met international capital standards, to consolidate weak banks with stronger ones, and to permit foreign investors to buy troubled banks. Complete deposit

\footnotetext{
${ }^{8}$ The chapter by Michael Mussa in this volume provides an unique and very detailed analysis of the myriad of changes called for in the different programs.
} 
insurance was to be eliminated so that depositors would have a greater incentive to monitor the risk-taking by the banks.

A second focus of structural reforms involved corporate finance and governance. The Fund called for substantial reductions in corporate leverage, major changes in accounting practices, and restructuring of corporate board memberships. Restrictions on foreign share ownership were to be eliminated and government-owned corporations were to be privatized. The legal structure was to be modified in various ways and bankruptcy procedures altered to increase the effective rights of creditors.

Much was made of "crony capitalism," that is, the granting of preferential treatment to favored companies, political allies, and members of the governing family. The fund pointed out that such behavior was not acceptable in countries like the US and the UK. Specific practices such as the granting of monopolies to particular companies or individuals were also to end.

The Fund required the end of many government subsidies, even of products like cooking oil that were widely purchased by low income households. Other changes involved labor laws, the provision of unemployment benefits and other social insurance, and tax reform. Barriers to trade and foreign direct investment were to be eliminated.

It is clear that these "mandatory" changes went far beyond what was necessary to stabilize the individual economies or to allow them to regain voluntary access to the global capital markets. The Fund had gotten into the habit in eastern Europe and the former Soviet Union of telling countries what it regards as "best practice" in a wide variety of aspects of national economic management. It now used the leverage that it had with the crisis countries to try to force such changes on them. The Fund's managing director, Michel Camdessus, once commented that the crises were a blessing in disguise because they provided the Fund with the opportunity to improve the economic structure and governance of these countries.

The Fund sometimes justified the far reaching structural programs as necessary to regain confidence in the country among foreign investors. In fact, of course, those investors had shown substantial confidence before the crisis, lending and investing large amounts of money. If they now interpreted the crises in the debtor countries as due to more than an overvalued exchange rate, a mismanaged international balance sheet, and an underdeveloped banking system, it was 
probably because of the IMF's very public criticism of what the Fund regarded as fundamental structural problems.

The demand for detailed changes in so many aspects of the countries' economies created local opposition to the Fund programs, both because they would hurt powerful special interests and because they were widely felt within the countries to be an overreaching by the Fund into subjects that should be left to national decision-making. Any attempt to deal with the full range of structural changes while also trying to manage a short-term recovery from the crisis put severe strains on government competence that made economic recovery and foreign debt negotiations more difficult.

The IMF, in an official review of its experience in the crisis countries, has now acknowledged that their structural programs were excessive ${ }^{9}$ and has said that in the future it would try to distinguish between those structural changes that are necessary for the success of the country's recovery from the crisis and those other structural changes that the Fund deems to be useful and desirable but not necessary for the country's recovery. It remains to be seen how well this distinction will work in practice. Moreover, even if the Fund does not insist on certain structural reforms in future crises, if it or the World Bank offers substantial financial incentives to make the change, it is politically very difficult for countries to resist accepting the offer.

At first, the political leaders in Indonesia, Korea and Thailand said that they would refuse to accept the IMF's conditions. They soon relented, saying that they would implement the plans and signing the agreements with the IMF in exchange for the promise that very large amounts of money would be paid as the program was implemented. In practice, however, the countries did not implement even those mandatory changes that seem most relevant to the success of their programs. They nevertheless generally received the funds that the Fund had said were conditional on adherence to the terms of the program.

In Korea, for example, the Fund placed great emphasis on eliminating the government's role in capital allocation and making the commercial banks fully independent, ending the tradition in which bank lending was subject to detailed Ministry of Finance guidance. What has

\footnotetext{
${ }^{9}$ Refocusing the IMF - An IMF Issues Brief by IMF Staff (IMF: Issues Brief 2001/03, April 2001). 
actually happened is that the government has infused substantial public money as equity in the banks in order to recapitalize them after their widespread losses and thus obtained a new basis for government control over the banks' activities. Although the banks' managements are in principle free to act without consulting their government owners, the actual practice keeps the government very much involved in major lending decisions, particularly to companies that are in trouble. Moreover, since the banks have become owners of many foreclosed nonfinancial corporations, the Korean government is in fact the indirect owner of these companies as well. Although the government of Korea is in principle willing to sell to foreign investors these banks and the nonfinancial corporations that the banks have acquired, there is in fact little desire to sell them at the prices that potential buyers would be willing to pay. There have been many negotiations but relatively few sales. Although the banking sector is improving, it will be a long time before Korea has an adequate number of experienced bankers who are capable of making loan decisions on strictly commercial considerations and evaluating credit risks more generally even if the government is willing to let them do so.

Korea has now graduated from its IMF program and repaid its IMF loans. It has accumulated foreign exchange reserves of more than $\$ 100$ billion and has an exchange rate that gives it a healthy balance of trade surplus. Korea clearly does not want to find itself again under IMF management.

How did the experience of the crisis countries affect the incentives of others: the lenders to be more careful in the future, the borrowers to reduce future risks, and countries facing potential future crises to come earlier to the IMF for assistance?

The crises were clearly painful experiences for the debtor countries and they are taking some steps to avoid a repetition of that pain. Korea's $\$ 100$ billion of foreign exchange is far more than the IMF has told Korea is adequate and prudent. Korea is nevertheless willing to incur the cost of holding those reserves because it does not want to find itself again under IMF supervision. That surplus and a floating exchange rate that produces large trade surpluses are likely to succeed in keeping Korea away from IMF supervision for as long as those conditions last. 
Many of the critics of the IMF's crisis management argue that the Fund's provision of large low-interest loans that can be used to repay foreign creditors creates a "moral hazard" problem in which emerging market countries and their creditors take excessive risk because they know that creditors will be paid relatively quickly in a crisis and without having to take substantial losses of principal. This causes a greater willingness to lend and keeps the interest rates on those loans substantially lower than they would otherwise be. The borrowers and the borrowing countries are then tempted by these relatively low interest commercial loans to borrow more than they should, particularly in dollars that cause a serious deflationary problem if the local currency devalues sharply.

There is no doubt that the large low interest loans provided by the IMF made it easier for the debtor countries to repay their creditors and therefore reduced the cost of the crisis to both debtors and creditors relative to what it would otherwise be. Whether this effect was large enough to make borrowers and lenders less vigilant than they would otherwise have been uncertain. And even if one can presume that some decrease in prudence would inevitably follow the provision of such subsidized lending, it is not clear whether the magnitude of the change in behavior is significant enough to be a problem.

Despite the loans from the IMF, the individuals who were directly involved suffered significant personal losses. The Finance Ministers in the debtor countries lost their jobs, the business owners in the debtor countries were frequently in bankruptcy, and the bankers involved on both sides of the transactions were often fired. The banks that loaned the money were frequently forced to roll over their loans, taking greater risk without adequate additional compensation. Bondholders were also forced to take some losses. For some while at least, the flow of both debt and equity funds to the emerging market countries as a group declined.

The large losses incurred on loans to Russia may have further reduced the moral hazard problem. Before the Russian default, it was widely assumed that because of Russia's nuclear arsenal and geopolitical importance, it would not be allowed to default. But the moral hazard risk was increased when the IMF provided Turkey with substantial financial support and gave a major loan to Argentina in 2001 when it was becoming clear that, because of the devaluation of the Brazilian real, Argentina would not be able to maintain its peg to the dollar. Nevertheless, the 
willingness of private lenders to maintain their loans to Argentina in 2001 shows a continued appetite for risk that some would regard as unwarranted and based on the assumption that the Fund would be there to help in a future crisis.

A quite different incentive effect of the IMF programs is on countries that see a potential crisis looming but do not want to put themselves in the hands of the IMF. Thailand, Indonesia and Korea all waited as long as they could before coming to the IMF. Their experience after coming to the IMF in 1997 is not likely to do anything to cause future governments in those countries or elsewhere to move more quickly to seek IMF help. There are many reasons why the political leaders of a country put off going to the IMF. Doing so indicates a failure of policy that is likely to be harmful in the next election. If the IMF requires floating the currency or devaluing the exchange rate, many local businesses will be adversely affected, no doubt including many who are close to the governing party. The experience in the recent crises is likely to convince political leaders in countries that face crises in the future that bringing in the IMF may lead to their own ouster and, even if they can stay in office, in a shift of power to the IMF staff. Waiting has the virtue that the crisis may be postponed and might even go away if the real exchange rate declines as a result of changes in the currencies of other trading partners and trade competitors.

If the IMF wants to be actively involved in preventing crises in individual countries as well as in dealing with those countries after crises occur, it cannot continue to be seen as a source of national pain and political embarrassment to the government in power. It must become a helpful resource to the countries that are approaching a crisis point. If it wants to reduce the risk of financial crises, the IMF must change its behavior during crises so that it is called upon at an earlier stage before a full scale crisis is inevitable.

Were the actions of the IMF politically legitimate for an international agency dealing with sovereign nations?

This politically powerful question cannot be given a technical answer. There is no doubt, however, that it is an extremely important question to the debtor countries that are required to accept IMF programs and to all of the countries that contemplate the chance of such an IMF intrusion in their domestic affairs. The United States does not and cannot think about the 
possibility of being a subject of such a program. But virtually every other country in the world can identify with the countries that have had IMF programs. The legitimacy of those programs themselves are therefore at stake.

It is clear from the experience of the past few years that the IMF is much more than an adviser and a source of credit to which countries are entitled by virtue of their membership in the Fund. When a country begins a program with the Fund, it signs a "letter of intent" that imposes certain obligations of the country. The extraordinarily large loans that the IMF can bring to a country puts its politicians in a position in which it would be very difficult if not impossible to reject the IMF's advice if it meant also foregoing the billions of dollars of economic help.

The power of the IMF to force its policies on countries raises the important question of the legitimate role of an international financial institution in dealing with sovereign countries. Even if the technical soundness of the IMF's prescriptions were beyond doubt, is it appropriate for the Fund to impose rules about such things as the role and independence of the central bank or the rights of workers or the nature of social insurance benefits of the country? My own judgement is that all such preemptive actions are inappropriate unless they are necessary to resolve the current crisis and to permit the debtor country to regain access to the international capital market. Extending the scope of mandatory policies to other things that the Fund's staff believe is in the long-run interest of the debtor country is not a legitimate part of the IMF's mandate. It is likely to do more harm than good by creating resistance to the program as a whole and by discouraging countries from seeking Fund help at an early stage.

In some cases, the Fund's staff based mandated structural reforms on the suggestions of the political party that was then out of power in the debtor country(and therefore critical of the policies of the existing government.) In Korea, for example, significant parts of the structural reforms were designed by the staff of the opposition presidential candidate at the time of the crisis. When he won the election, those policies became the policies of the president . These policies could not however have been turned into laws without IMF leverage because the democratically elected parliament had not changed political parties. While the Fund's staff pointed to the support for those parts of the program by the new Korean president, it remains true 
that the program had to be imposed because it could not obtain the political support needed to be enacted according to the country's constitutional rules.

The appropriateness of the Fund's imposition of detailed structural policies is made even more questionable by uncertainty about the technical correctness of the Fund's advice. Fashions in economic policy change over the years. A generation ago, the conventional wisdom favored fixed exchange rates and many economists believed that a country should aim to grow by substituting domestic production for foreign imports. Today the Fund promotes flexible exchange rates and most economists support the pursuit of comparative advantage in trade. A generation from now, will the policies that the IMF now imposes on countries still be deemed to have been correct?

What were the political consequences of the crises and the policies that followed?

The appropriateness of the IMF's programs cannot be evaluated without considering the political consequences of the Fund's programs on the crisis countries and on the relation of those countries and other emerging market nations to the industrial countries in general and to the United States in particular.

The Fund was originally conceived of as a kind of mutual assistance organization to which countries made financial contributions and from which they could borrow funds in times of temporary financial crisis. With the shift of its activities from the industrial countries to the emerging market economies, the Fund might be seen as a way in which the industrial countries provide assistance to the emerging market nations when they get into trouble. There is a danger, however, the Fund is instead viewed as the agent of the industrial countries that lends in times of crisis so that the creditor banks and bond holders in the industrial countries can be repaid, using the leverage of the Fund's credit line and approval process to force the debtor countries to make changes that benefit the business community in the G-7 countries. The U.S. Congress and other national parliaments in the G-7 countries are prepared to vote large sums for the IMF and for bilateral assistance only on the condition that the IMF impose policies that benefit their business and labor constituents. 
The statements of officials in the debtor countries are not a useful basis for assessing their true attitudes since they remain dependent on the good will of the Fund and the creditor countries. The actions and statements of the nongovernment organizations that decry globalization and the international financial organizations may be equally misleading in the opposite direction as a true indication of the opinions of the public and the elites in the emerging market countries.

The long-term political effects of the Fund programs within the debtor countries are no less difficult to evaluate. The humiliation of the government and its leaders, the shift of power from the national government to the IMF, and the radical reforms imposed by the Fund can all have powerful effects on domestic politics in both the short run and the longer term. Indonesia is a good example of this process. Indonesia is a large and strategically located country with the second largest Moslem population in the world. The actions of the IMF in Indonesia led to the resignation of President Suharto and the introduction of a series of short-term and weak national leaders. The specific policies were particularly hard on urban workers and the urban poor, politically volatile groups in any emerging market country. Even now, several years later, the political future and stability of Indonesia is unclear and civil war exists in important regions of the country. The eventual dissolution of Indonesia as a single nation cannot be ruled out and the geopolitical consequences of such a dissolution cannot be foreseen.

Even before Suharto's resignation, the IMF's policies demonstrated that he had lost control of the government. When that occurred, many of the important Chinese minority in Indonesia left out of fear for their personal safety and for the dangers to their businesses. Suharto had protected the Chinese minority because he valued their central role in providing entrepreneurship, capital, and global market connections for Indonesia. Suharto's resignation made it much more difficult to achieve economic stability and contributed to the political uncertainty and instability that has characterized Indonesia since then.

The IMF programs also coincided with changes in political leadership in Korea and Thailand. It may be because the conditions that forced the authorities to call in the IMF also caused the local voters to want a different group to govern. However, that did not happen in Malaysia where the financial crisis also caused economic decline but where Prime Minister 
Mahathir did not accept an IMF program. There are too many political factors that are specific to each country to draw any firm conclusions. But there were not doubt officials at the IMF who believed that the fundamental economic restructuring that the Fund wanted could only be carried out if there was a change in the local government leadership. Quite apart from the inappropriateness of an IMF strategy that includes encouraging a change of government, there is the obvious adverse incentive effect that such behavior has on the willingness of any government to seek IMF help at an early stage.

The painful IMF programs antagonized the people of the recipient countries who objected to the policies imposed by the Fund and to the way in which those policies were imposed. The harsh public criticisms by the Fund were a blow to the pride of the people who had seen their countries as the Asian miracle just a few years earlier.

This antagonism was directed not only at the Fund but at the western nations generally and at the United States in particular because it was seen as the power that dictated the Fund's programs. Critics were aware that some of the Fund's "reform conditions" were required by the U.S., Japan and European countries seeking market opening for their products and services. They particularly resented the pressure to sell domestic firms to foreign buyers at what they believed would be "fire sale" prices during the crisis and early recovery years.

It is not easy for the residents of the debtor countries or even for their sophisticated elites to distinguish the painful effects of the crises that they brought upon themselves from the pain of the macroeconomic adjustments and radical structural reforms that the IMF imposed. But the experience as a whole no doubt contributed to a general distrust of "globalization" and of western institutions in all of the emerging market countries. For many groups in these countries, the experience also increased the distaste for the market system and for capitalism. The long term consequences of these changes may be the most serious and lasting effects of the crises.

Cambridge, MA

Fincurcris.intro.03052002.wpd $-36-$ 